\title{
Rare-earth ions as antibacterial agents for woven wool fabric
}

\author{
Shota Akioka ${ }^{1}$ Shinji Hirai ${ }^{1}$ Kenta lijima ${ }^{1} \cdot$ Akihiro Hirai $^{2} \cdot$ Mohammed Abdullah Hamad Alharbi $^{1}$
}

Received: 26 August 2021 / Accepted: 26 November 2021 / Published online: 14 February 2022

(c) Institute of Chemistry, Slovak Academy of Sciences 2022

\begin{abstract}
Woven fabrics were bestowed with antibacterial property by the simple adsorption of rare-earth metal ions, and the underlying mechanism was investigated using electron spin resonance (ESR) spectroscopy. The adsorption of $\mathrm{Ce}^{3+}$ ions on wool, silk, and cotton fabrics resulted in significant inhibition of Staphylococcus aureus (a gram-positive bacterium), with maximum antibacterial activities (viable bacterial count compared to the reference) of 4.7, 5.8, and 5.2, respectively. Even after 50 wash cycles, the values remained at 3.9, 2.9, and 4.8, respectively. The adsorption of $\mathrm{La}^{3+}$ and $\mathrm{Gd}^{3+}$ ions on wool fabrics also resulted in antibacterial activities of 5.8 and 5.9, respectively. In addition, wool adsorbed with $\mathrm{Ce}^{3+}$ exhibits a satisfactory antibacterial activity of 6.2 against Escherichia coli (a gram-negative bacterium). Such bacterial inhibition is attributed to Fenton reactions between the adsorbed rare-earth ions and hydrogen peroxide $\left(\mathrm{H}_{2} \mathrm{O}_{2}\right)$ produced during bacterial metabolism, as determined from the ESR spectra collected using the spin trap method in the presence of $\mathrm{H}_{2} \mathrm{O}_{2}$. The safety of cerium nitrate was also investigated, and no significant issues arose, indicating that it was a safe antibacterial agent. This facile method of imparting antibacterial properties to natural fabrics may be useful for preventing infections in humans.
\end{abstract}

Keywords Rare-earth ions $\cdot$ Wool $\cdot$ Cerium $\cdot$ Antibacterial activity $\cdot$ Adsorption $\cdot$ Fabric treatment

\section{Introduction}

Existing antibacterial/deodorizing finishing agents used in fabrics include quaternary ammonium salts (i.e., cationic surfactants as the main component of invert soap), organic compounds such as triclosan, and inorganic compounds, including silver ions supported on zeolite, titanium oxide, and zinc oxide (Bekrani et al. 2020; Espitia et al. 2012; Galal et al. 2011; Ghiasi et al. 2021; Lu et al. 2007; Zhang et al. 2009). For example, silver is often used as an antibacterial substance, although it may have genotoxicity and its carcinogenic potential is needed to assess additionally (Hadrup et al. 2018; Wen et al. 2017). Inorganic antibacterial agents exhibit excellent thermal stability and good durability; however, they are more expensive than organic compounds (Yamamoto and Sawai 2002).

Shota Akioka

19096001@ mmm.muroran-it.ac.jp

1 Research Center of Environmentally Friendly Materials Engineering, Muroran Institute of Technology, 27-1 Mizumoto-cho, Muroran, Hokkaido 050-8585, Japan

2 NTT Medical Center Tokyo, 5 Chome-9-22 Higashigotanda, Shinagawa City, Tokyo 141-8625, Japan
The antibacterial activity of silver ions is attributed to the strong binding of the eluted silver ions onto the thiol group (-SH) of cysteine in bacteria (Yuan et al. 2013), which facilitates the formation of a silver complex. Silver may be excreted extracellularly as a soluble or sparingly soluble compound (e.g., stable silver sulfate or metallic silver) or through sequestration in proteins containing large numbers of -SH groups (Russell and Hugo 1994) and nitrogen groups (-N-) (Izatt et al. 1971). Moreover, silver ions can kill bacteria by interfering with their metabolic system, demonstrating bactericidal activity (Yamamoto 1999).

The antibacterial property of woven wool fabric increases slightly after immersion in an aqueous solution of silver nitrate $\left(\mathrm{AgNO}_{3}\right)$. However, wool contains $\sim 85 \%$ keratin (Bradbury 1973; Kulkarni and Baumann 1980), which includes $10.5 \mathrm{~mol} \%$ air-oxidized cysteine (Bradbury 1973). The sulfur therein can react with silver to produce $\mathrm{Ag}_{2} \mathrm{~S}$ and cause fabric discoloration (Tsukada 2004). Therefore, silver compounds are not suitable antibacterial agents for wool products. However, the alternatives of $\mathrm{ZnO}$ and $\mathrm{TiO}_{2}$ are activated under UV irradiation, but the amount of UV exposure fluctuates widely during the course of the day (Gaya and Abdullah 2008; Eren et al. 2015). 
The demand for rare-earth elements in Japan has decreased to approximately one-third of the peak value due to various factors such as a sharply reduced need for abrasives (Japan Oil, Gas and Metals National Corporation (JOGMEC) 2015; Morimoto and Seo 2014). Despite growing demand for certain elements (especially praseodymium, neodymium, dysprosium, and terbium for magnets), light rare-earth elements such as yttrium, lanthanum, and cerium are now in excess due to the balance of rare-earth ore composition. Rare-earth ions can be obtained in the form of sulfates from waste treatment using sulfation and in the form of acid salts from the leaching stage (Ren et al. 2018). Thus, the development of effective applications of these ions, especially in the form of nitrides, is valuable. Furthermore, cerium nitrate is present in the spent nuclear fuel from nuclear power plants (Sanpei et al. 2002), and its effective use can help reduce the environmental pollution caused by such effluents. Therefore, we believe that this technology can be environmentally friendly in terms of process, energy saving, and the effective use of waste materials.

Several studies have demonstrated the use of light rareearth elements as antibacterial agents, especially the relatively more abundant cerium (Lin et al. 2007; Liu 2007; Manikandan et al. 2017; Nose and Okabe 2012; Pourkhorsandi et al. 2021; Shah et al. 2012). Recently, the complex oxide $\mathrm{La}_{2} \mathrm{Mo}_{2} \mathrm{O}_{9}$ (LMO) was found to have hydrophobic properties and antibacterial effects against gram-negative and gram-positive bacteria. It also inhibited non-enveloped (bacteriophage $\mathrm{Q} \beta$ ) and enveloped (bacteriophage $\Phi 6$ ) viruses (Matsumoto 2019). $\Phi 6$ resembles and can be used as a surrogate for influenza viruses and SARS-CoV-2 (the pathogen causing COVID-19) (Ito et al. 2021; Wang et al. 2020). Matsumoto et al. (2020) reported that the activity of LMO against bacteriophage $\Phi 6$ can be improved by substituting lanthanum with cerium. Moreover, $\gamma-\mathrm{Ce}_{2} \mathrm{Mo}_{3} \mathrm{O}_{13}$ exhibited high activity against both $\Phi 6$ and SARS-CoV-2, possibly due to the valence fluctuation of cerium (Ito et al. 2021). Cerium has two stable ionic forms, namely $\mathrm{Ce}^{3+}$ and $\mathrm{Ce}^{4+}$. $\mathrm{Ce}^{3+}$ has one $4 \mathrm{f}$ electron that is nearly the same as the outer $5 \mathrm{~d}$ and $6 \mathrm{~s}$ electrons that are lost upon ionization; thus, cerium can also form $\mathrm{Ce}^{4+}$, which is unique among rareearth metals. Heckert et al. (2008) attributed such a high activity to a "Fenton-like reaction" through the valence fluctuation of cerium. The hydroxyl radical $(\cdot \mathrm{OH})$ has high antibacterial activity owing to the strong oxidizing property, as indicated by its very positive standard electrode potential among reactive oxygen species. It damages not only the cell walls but also the entire microbe. Iron is a strong redox cycling metal and is known to react with hydrogen peroxide $\left(\mathrm{H}_{2} \mathrm{O}_{2}\right)$ to produce $\cdot \mathrm{OH}$ via the Fenton reaction (Heckert et al. 2008; Imlay 1988). Similarly, copper, cadmium, chromium, mercury, nickel, and vanadium have all been reported to generate reactive radicals in the presence of $\mathrm{H}_{2} \mathrm{O}_{2}$ (Matsumoto 2020; Valko et al. 2005).

Wool is used to make sweaters, suits, etc., and approximately 1 million tons of wool are produced per year (International Wool Textile Organisation 2016). Natural fibers have many hydrophilic $(-\mathrm{OH}$ and $-\mathrm{COOH})$ groups, which have a high affinity for metals. In particular, in wool keratin, amino acids with nitrogen-containing side chains (lysine, arginine, and particularly histidine) exhibit a strong affinity toward metal ions (Craig et al. 1954; Cuadrado et al. 2000). However, the outer layer of wool cuticle cells (scales) is protected by a high degree of cystine cross-linking, and the surface is hydrophobic. In a previous study, we used chlorine treatment to remove these cuticular cells, which drastically improved metal cation adsorption (Akioka et al. 2021).

This study investigates the antibacterial property of natural fibers (particularly wool) adsorbed with light rare-earth ions using simple immersion in solutions of light rare-earth salts (nitrates; primarily, cerium nitrate). Furthermore, the underlying mechanism of antibacterial action in the rareearth-adsorbed fabric is elucidated. We also compared the antibacterial activities following treatment using other rareearth elements. Finally, we tested the proposed treatment on silk and cotton fabrics.

\section{Experimental}

\section{Materials}

Woven fabric of merino wool was supplied by The Japan Wool Textile. Co., Ltd., Osaka, Japan. The average diameter of a single wool fiber was $20.5 \mu \mathrm{m}$. Chlorination was carried out by passing the fabric through a solution comprising sodium hypochlorite and potassium permanganate. This is a standard industrial anti-shrinkage treatment method followed by suppliers (Kawahara 1981).

A mixed solution was prepared with $10 \mathrm{mg} \mathrm{L}^{-1}$ each of 16 kinds of rare-earth ions. The solution contained inductively coupled plasma (ICP) standard solution F, cerium (III) nitrate $\left(\mathrm{Ce}\left(\mathrm{NO}_{3}\right)_{3}\right)$, cerium (IV) diammonium nitrate $\left(\left(\mathrm{NH}_{4}\right)_{2}\left[\mathrm{Ce}\left(\mathrm{NO}_{3}\right)_{6}\right]\right)$, lanthanum (III) nitrate $\left(\mathrm{La}\left(\mathrm{NO}_{3}\right)_{3}\right)$, gadolinium (III) nitrate $\left(\mathrm{Gd}\left(\mathrm{NO}_{3}\right)_{3}\right)$, and cerium (III) acetate hydrate $\left(\mathrm{Ce}\left(\mathrm{CH}_{3} \mathrm{COO}\right)_{3} \cdot \mathrm{H}_{2} \mathrm{O}\right)$. These chemicals were purchased from Kanto Chemical Co., Inc., Tokyo, Japan. Other chemicals were purchased from Solvay Special Chem, Tokushima, Japan. In some experiments, powdered $\mathrm{CeO}_{2}$ (Solvay Special Chem) was used in place of $\mathrm{Ce}\left(\mathrm{NO}_{3}\right)_{3}$ to produce a high $\mathrm{pH}$ immersion liquid. Electron spin resonance (ESR) measurements were performed using $\mathrm{H}_{2} \mathrm{O}_{2}$ (Kanto Chemical Co. Inc.), and 5-(2,2-dimethyl1,3-propoxycyclophosphoryl)-5-methyl-1-pyrroline $N$-oxide (CYPMPO) (Cayman Chemical Co., Ltd.) was used as a 
spin-trapping agent. The $\mathrm{Ce}\left(\mathrm{NO}_{3}\right)_{3}$ used in the safety test was provided by Santoku Corporation, Hyogo, Japan.

The wool surfaces were examined by scanning electron microscopy (SEM) (JSM-6610LA, JEOL Corporation, Tokyo, Japan) at an accelerating voltage of $20 \mathrm{kV}$ and magnifications of $\times 1000, \times 2500$, and $\times 5000$.

\section{ICP mass spectrometry}

The concentrations of various ions in the aqueous solution were quantified using inductively coupled plasma-atomic emission spectrometry (ICP-AES) (ICPE-9800, Shimadzu, Kyoto, Japan). The woven fabric was immersed in the mixed standard solution containing $10 \mathrm{mg} \mathrm{L}^{-1}$ each of 16 kinds of rare-earth ions at an input of $10 \mathrm{~g}$ of fabric per liter of solution (referred to as $\mathrm{g} \mathrm{L}^{-1}$ fabric to solution hereafter) and stirred at room temperature $\left(20-25{ }^{\circ} \mathrm{C}\right)$ for $24 \mathrm{~h}$. The recovery of the rare-earth ions was defined as the change ratio of metal concentration after immersion:

Recovery $(\%)=\left[\left(C_{\mathrm{b}}-C_{\mathrm{a}}\right) / C_{\mathrm{b}}\right] \times 100$,

where $C_{\mathrm{a}}$ and $C_{\mathrm{b}}$ are the metal ion concentrations after and before immersion, respectively.

\section{Antibacterial treatment of woven wool fabric}

Wool with an input of $10 \mathrm{~g} \mathrm{~L}^{-1}$ fabric to solution was immersed in an aqueous solution of $\mathrm{Ce}\left(\mathrm{NO}_{3}\right)_{3}$ with a cerium concentration of $5 \%$ o.w.f (the weight of antibacterial agents against the weight of fiber). In some tests, $12 \%$ o.w.f cerium (III) acetate $\left(\mathrm{Ce}\left(\mathrm{CH}_{3} \mathrm{COO}\right)_{3}\right)$ was used instead of $\mathrm{Ce}\left(\mathrm{NO}_{3}\right)_{3}$ at the same concentrations to increase the $\mathrm{pH}$ of the immersion liquid. The immersion time ranged from $40 \mathrm{~min}$ to $48 \mathrm{~h}$. Following immersion, the fabric was thoroughly washed with water, dried at room temperature, and then subjected to antibacterial tests. Furthermore, the woven fabric was washed 10 or 50 times for 4 min following Japanese Industrial Standard (JIS) L-2017-103, and the antibacterial activity was then evaluated after each wash cycle and the final wash cycle to determine the suitability for practical application.

Three immersion liquids were prepared using $\left(\mathrm{NH}_{4}\right)_{2}\left[\mathrm{Ce}\left(\mathrm{NO}_{3}\right)_{6}\right], \mathrm{La}\left(\mathrm{NO}_{3}\right)_{3}$, or $\mathrm{Gd}\left(\mathrm{NO}_{3}\right)_{3}$ at the concentrations mentioned above. Another suspension contained 10\% o.w.f $\mathrm{CeO}_{2}$ powder in distilled water. We evaluated the antibacterial properties of fabrics following immersion in these four liquids, as well as that of pure $\mathrm{CeO}_{2}$ powder.

\section{Antibacterial analysis}

The antibacterial properties were analyzed following the protocol outlined in JIS L 1902:2015 and ISO 20743. Before analysis, all fabric samples were sterilized in an autoclave. Subsequently, $0.2 \mathrm{~mL}$ of solution containing Escherichia coli (gram negative) or Staphylococcus aureus (gram positive, $1-3 \times 10^{5}$ colony forming units $\mathrm{mL}^{-1}$ ) and $0.05 \%$ of a nonionic surface-active agent (Tween 80, Bio Medical Science, Tokyo, Japan) were inoculated onto the woven fabric samples (Fig. 1). A fabric without rare-earth element treatment was used as the control.

After culturing the inoculated samples for $18 \mathrm{~h}$ in a dark room at $37 \pm 2{ }^{\circ} \mathrm{C}$, the bacteria were washed from the fabrics using a standard saline solution. The number of viable bacteria in the post-wash solution was determined following a pour plate method. The antibacterial activity was defined
Fig. 1 Procedures for chlorine pretreatment, rare-earth adsorption, and antibacterial activity test

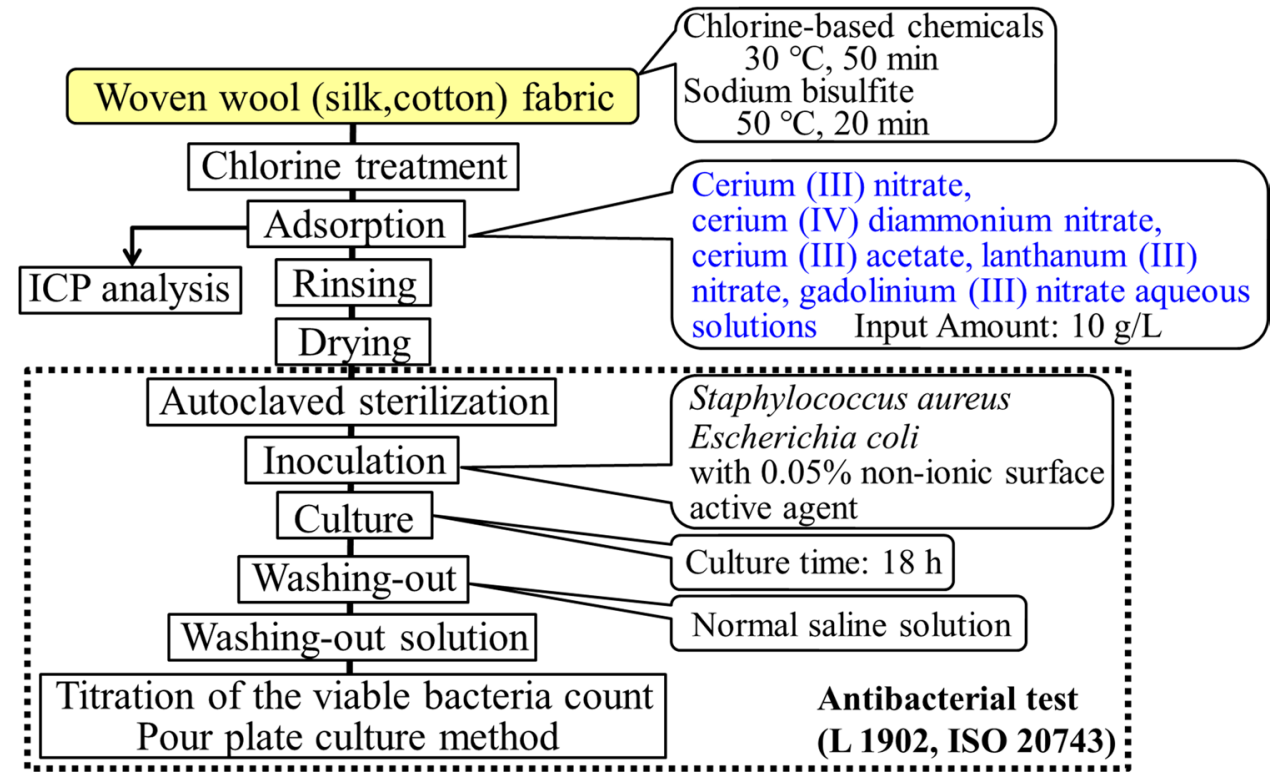


in terms of viable bacteria count compared to the reference. The mathematical equation is given as follows: detailed experimental procedure is shown in Electronic Supplementary Material. These tests were conducted at

Antibacterial activity $=\log \left(C_{\text {ref_culture }} / C_{\text {ref_inoc }}\right)-\log \left(C_{\text {s_culture }} / C_{\text {s_inoc }}\right)$,

where $C_{\text {ref_culture }}$ and $C_{\text {ref_inoc }}$ are the viable bacteria counts on the reference (untreated) fabric after culturing and immediately after inoculation, respectively, and $C_{\text {s_culture }_{\text {cund }}}$ and $C_{\mathrm{s} \_ \text {inoc }}$ are the corresponding counts on the treated fabric sample. An activity value of 2 or higher indicates antibacterial effect.

The antibacterial properties of cerium-ion-adsorbed fabric samples were tested after 50 detergent wash cycles in an electric washing machine at $40{ }^{\circ} \mathrm{C}$. Each cycle consisted of the following steps: 5 min washing, purging, 2 min rinsing, air drying, 2 min rinsing, spinning, and line drying.

\section{ESR spectroscopy}

The formation of active oxygen free radicals in the reaction between $\mathrm{H}_{2} \mathrm{O}_{2}$ and $\mathrm{Ce}^{3+}$ adsorbed on the woven fabric surface was monitored using ESR spectroscopy (X-Band CW Electron Spin Resonance, Bruker EMX Plus). $\mathrm{H}_{2} \mathrm{O}_{2}$ is produced in bacterial mitochondria during energy metabolism. To observe unstable and short-lived free radicals through ESR spectroscopy, it is necessary to stabilize them; thus, the spin trap method was used. First, woven fabrics with adsorbed $\mathrm{Ce}^{3+}, \mathrm{La}^{3+}$, or $\mathrm{Gd}^{3+}$ (the sample shape did not affect the results) were immersed in an $\mathrm{H}_{2} \mathrm{O}_{2}$ aqueous solution $\left(1.6 \mu \mathrm{M} ; 6.7 \mathrm{~g} \mathrm{~L}^{-1}\right.$ fabric to solution). The sample was stabilized at $25^{\circ} \mathrm{C}$ for $30 \mathrm{~min}$. Subsequently, $200 \mu \mathrm{L}$ of the immersion liquid was taken and added to CYPMPO (a spin trap agent) and stirred, followed by ESR analysis. All rareearth metal ions were modified using each nitrate solution described above.

\section{Safety of cerium nitrate}

The safety of $\mathrm{Ce}\left(\mathrm{NO}_{3}\right)_{3}$ in the immersion liquid for antibacterial treatment was evaluated through an in vitro skin irritation test (OECD Guidelines for the Testing of Chemicals (GTC) No. 439) using a human 3D cultured epidermis model (LabCyte EPI-MODEL24 SIT, Japan Tissue Engineering Co., Ltd., Aichi, Japan). In addition, a microbial mutagenicity test (Occupational Safety and Health Law in Japan) was conducted with Salmonella typhimurium (TA100, TA1535, TA98, and TA1537) and E. coli (WP2uvrA) using the pre-incubation method. Finally, a skin sensitization test (OECD GTC, No. 442B) was performed on a CBA/J mouse using the local lymph node assay (LLNA): BrdU-ELISA. Next, an acute oral toxicity test (OECD GTC, No. 420) was conducted on female $\mathrm{Crl}: \mathrm{CD}(\mathrm{SD})$ rats. The the Japan Chemical Innovation and Inspection Institute in accordance with the following laws, guidelines, and standards: (a) Act on the Welfare and Management of Animals, Law No. 105, 1973; (b) Standards for the Care and Custody of Animal Experiments and for the Alleviation of Pain and Suffering, Japan's Ministry of the Environment, 2006; (c) Basic Guidelines for the Implementation of Animal Experiments, etc., in Institutions Complementary to the Ministry, Japan's Ministry of Health, Labour and Welfare, 2006; (d) Basic Guidelines for the Implementation of Animal Experiments, etc., in Research Institutions under the Jurisdiction of the Ministry, Japan's Ministry of Agriculture, Forestry and Fisheries, 2006; (e) Basic Guidelines for the Implementation of Animal Experiments, etc., in Research Institutions, etc., Japan's Ministry of Education, Culture, Sports, Science and Technology, 2006; and (f) Guidelines for the Appropriate Implementation of Animal Experiments, Science Council of Japan, 2006.

\section{Results}

\section{Influence of chlorination on rare-earth adsorption}

Figure 2 shows SEM images of the chlorinated woven wool fabric before and after immersion in a $\mathrm{Ce}\left(\mathrm{NO}_{3}\right)_{3}$ aqueous solution. No particles were observed on the surface of wool fibers descaled by chlorination, especially after the antibacterial treatment. This indicates that $\mathrm{Ce}^{3+}$ was adsorbed on the fabric and that it left no residue.

To investigate the influence of chlorination on the adsorption of rare-earth ions on woven wool fabrics, chlorinated and non-chlorinated fabrics were immersed in a standard solution containing $10 \mathrm{mg} \mathrm{L}^{-1}$ of 16 rare-earth ions for a period of $24 \mathrm{~h}$ at room temperature. Then, the recovery of each type of rare-earth ion was determined. As shown in supplementary Fig. S-1, chlorination enhanced the recovery for each rare-earth element by two- or threefold. Scandium, europium, and thulium could be recovered in high amounts. However, selective recovery was not achieved.

\section{Antibacterial activity}

Table 1 compares the antibacterial activities of the chlorinated woven wool fabrics toward $S$. aureus. When the immersion liquid contained $5 \%$ o.w.f $\mathrm{Ce}\left(\mathrm{NO}_{3}\right)_{3}$, the chlorinated fabric treated at $65{ }^{\circ} \mathrm{C}$ for $40 \mathrm{~min}$ demonstrated 
Fig. 2 SEM images of chlorinated wool surface before $(\mathbf{a}, \mathbf{c}$, e) and after $(\mathbf{b}, \mathbf{d}, \mathbf{f})$ Ce adsorption. The fabric was immersed in a $5 \%$ o.w.f $\mathrm{Ce}\left(\mathrm{NO}_{3}\right)_{3}$ aqueous solution at $98{ }^{\circ} \mathrm{C}$ for $40 \mathrm{~min}$ at an input of $10 \mathrm{~g} \mathrm{~L}^{-1}$ fabric to solution, washed with running water, and then air-dried
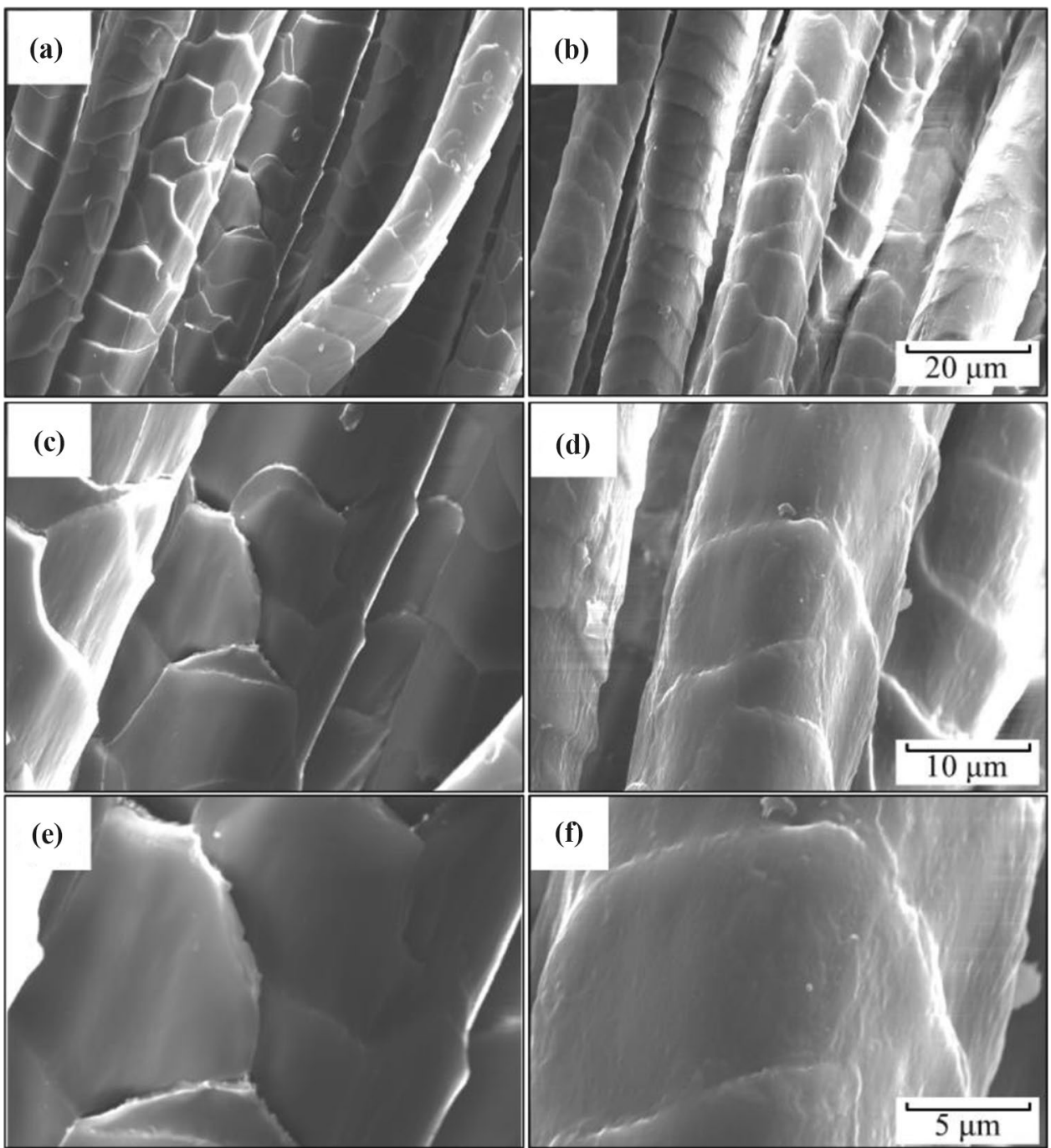

Table 1 Antibacterial activity of chlorinated woven wool fabrics toward S. aureus after different antibacterial treatments

\begin{tabular}{|c|c|c|c|c|}
\hline \multirow[t]{2}{*}{ Agent } & \multirow[t]{2}{*}{ Treatment conditions } & \multicolumn{2}{|c|}{ Logarithm of viable bacteria count } & \multirow{2}{*}{$\begin{array}{l}\text { Antibacte- } \\
\text { rial activity }\end{array}$} \\
\hline & & $\begin{array}{l}\text { Just after inocu- } \\
\text { lation }\end{array}$ & After culture & \\
\hline $\mathrm{Ce}\left(\mathrm{NO}_{3}\right)_{3}$ & $5 \%$ o.w.f, $65^{\circ} \mathrm{C}, 40 \mathrm{~min}$ & 4.48 & 5.32 & 1.7 \\
\hline $\mathrm{Ce}\left(\mathrm{NO}_{3}\right)_{3}$ & $5 \%$ o.w.f, $98^{\circ} \mathrm{C}, 40 \mathrm{~min}$ & 4.35 & 2.32 & 4.7 \\
\hline $\mathrm{Ce}\left(\mathrm{CH}_{3} \mathrm{COO}\right)_{3}$ & $5 \%$ o.w.f, $65^{\circ} \mathrm{C}, 40 \mathrm{~min}$ & 4.51 & 2.19 & 4.9 \\
\hline $\mathrm{Ce}\left(\mathrm{CH}_{3} \mathrm{COO}\right)_{3}$ & $5 \%$ o.w.f, $85^{\circ} \mathrm{C}, 40 \mathrm{~min}$ & 4.53 & 2.08 & 5.0 \\
\hline
\end{tabular}

poor antibacterial activity toward $S$. aureus (1.7), which can be attributed to the low $\mathrm{Ce}^{3+}$ adsorption. When the $\mathrm{Ce}\left(\mathrm{CH}_{3} \mathrm{COO}\right)_{3}$ aqueous solution was used for $40 \mathrm{~min}$ instead, high antibacterial activity was observed (approximately 4.9 and 5.0 at 65 and $85{ }^{\circ} \mathrm{C}$, respectively). In particular, as shown in Table 1, a higher immersion temperature led to enhanced antibacterial activity. After $\mathrm{Ce}^{3+}$ adsorption, no signs of fabric discoloration were observed.
Table 2 compares the antibacterial activities against $S$. aureus from chlorinated wool without rare-earth treatment (control fabric) and after treatment with $\mathrm{Ce}\left(\mathrm{NO}_{3}\right)_{3}$, $\left(\mathrm{NH}_{4}\right)_{2}\left[\mathrm{Ce}\left(\mathrm{NO}_{3}\right)_{6}\right]$, or $\mathrm{Ce}\left(\mathrm{CH}_{3} \mathrm{COO}\right)_{3}$ aqueous solution. Data were recorded before and after predetermined washing cycles. On the control fabric, the bacteria count increased after culturing regardless of the number of washing cycles, and the negative activity $(-0.6)$ indicated that the fabric 
Table 2 Antibacterial activity of rare-earth-treated chlorinated woven wool fabrics toward $S$. aureus before and after specific washing cycles (treatment conditions: $5 \%$ o.w.f, $98{ }^{\circ} \mathrm{C}$, $40 \mathrm{~min}$ )

Table 3 Antibacterial activity of the $\mathrm{CeO}_{2}$ powder and chlorinated woven wool fabric immersed in $\mathrm{CeO}_{2}$ sol

\begin{tabular}{lllll}
\hline Agent & Washing condition & \multicolumn{2}{l}{ Logarithm of viable bacteria count } & $\begin{array}{c}\text { Antibacte- } \\
\text { rial activity }\end{array}$ \\
\cline { 3 - 5 } & & $\begin{array}{l}\text { Just after } \\
\text { inoculation }\end{array}$ & After culture & \\
\hline No antibacterial treatment & Before washing & 4.49 & 7.58 & -0.6 \\
$\mathrm{Ce}\left(\mathrm{NO}_{3}\right)_{3}$ & Before washing & 4.35 & 2.32 & 4.7 \\
& After 10 washes & 4.35 & 2.31 & 4.7 \\
& After 50 washes & 4.36 & 3.20 & 3.9 \\
$\left(\mathrm{NH}_{4}\right)_{2}\left[\mathrm{Ce}\left(\mathrm{NO}_{3}\right)_{6}\right]$ & Before washing & 4.42 & 1.94 & 5.1 \\
& After 10 washes & 4.47 & 1.98 & 5.1 \\
& After 50 washes & 4.32 & 4.06 & 3.0 \\
$\mathrm{Ce}\left(\mathrm{CH}_{3} \mathrm{COOH}\right)_{3}$ & Before washing & 4.53 & 2.08 & 5.0 \\
& After 50 washes & 4.53 & 4.08 & 3.0 \\
\hline
\end{tabular}

\begin{tabular}{|c|c|c|c|c|}
\hline \multirow[t]{2}{*}{ Bacteria } & \multirow[t]{2}{*}{ Sample } & \multicolumn{2}{|c|}{ Logarithm of viable bacteria count } & \multirow{2}{*}{$\begin{array}{l}\text { Anti- } \\
\text { bacterial } \\
\text { activity }\end{array}$} \\
\hline & & $\begin{array}{l}\text { Just after inocula- } \\
\text { tion }\end{array}$ & After culture & \\
\hline S. aureus & $\mathrm{CeO}_{2}$ powder & $<1.3$ & $<1.3$ & $\geq 2.6$ \\
\hline E. coli & $\mathrm{CeO}_{2}$ powder & $<1.3$ & $<1.3$ & $\geq 3.1$ \\
\hline S. aureus & $\begin{array}{l}\text { Wool treated with } \mathrm{CeO}_{2} \text { sol }(10 \% \\
\left.\text { o.w.f, } 98^{\circ} \mathrm{C}, 40 \mathrm{~min}\right)\end{array}$ & 4.42 & 7.50 & -0.5 \\
\hline
\end{tabular}

did not inhibit bacterial growth. The fabrics treated with $\mathrm{Ce}\left(\mathrm{NO}_{3}\right)_{3}$ and $\left(\mathrm{NH}_{4}\right)_{2}\left[\mathrm{Ce}\left(\mathrm{NO}_{3}\right)_{6}\right]$ aqueous solutions demonstrated considerable antibacterial activity (approximately 4.7 and 5.0, respectively), both immediately after treatment and after 10 wash cycles. The activity decreased after 50 washes but still remained substantial. This implies that the antibacterial activity is unaffected by the valence of cerium.

The 5\% o.w.f $\mathrm{Ce}\left(\mathrm{NO}_{3}\right)_{3}$ aqueous solution was strongly acidic $\left(\mathrm{pH}^{<} 1\right)$, whereas the $\mathrm{pH}$ was 3.8 in the $\mathrm{Ce}\left(\mathrm{CH}_{3} \mathrm{COO}\right)_{3}$ aqueous solution. Fabric samples treated with these solutions at $98{ }^{\circ} \mathrm{C}$ for periods exceeding 40 min demonstrated high antibacterial activities (4.7 and 5.0, respectively) before washing, and after 50 cycles, the activities remained at 3.9 and 3.0, respectively.

Table 3 compares the antibacterial activities of $\mathrm{CeO}_{2}$ powder and chlorinated wool fabric immersed in $\mathrm{CeO}_{2}$ suspension (10\% o.w.f). Although the pure $\mathrm{CeO}_{2}$ powder had some antibacterial activity $(\geq 2.6$ toward $S$. aureus and $\geq 3.1$ toward E. coli), fabrics treated with a $\mathrm{CeO}_{2}$ sol (10\% o.w.f) at $98{ }^{\circ} \mathrm{C}$ for $40 \mathrm{~min}$ failed to inhibit $S$. aureus (antibacterial activity: -0.5$)$. This means that the $\mathrm{CeO}_{2}$ particles did not adhere to the wool surface.

Table 4 lists the antibacterial activities toward S. aureus when chlorinated woven wool fabric was immersed in $\mathrm{Ce}\left(\mathrm{NO}_{3}\right)_{3}, \mathrm{La}\left(\mathrm{NO}_{3}\right)_{3}$, and $\mathrm{Gd}\left(\mathrm{NO}_{3}\right)_{3}$ aqueous solutions under similar conditions. The antibacterial activities were 4.7, 5.8, and 5.9 , respectively.
Table 4 Antibacterial activity of chlorinated woven wool treated with $\mathrm{Ce}\left(\mathrm{NO}_{3}\right)_{3}, \mathrm{La}\left(\mathrm{NO}_{3}\right)_{3}$, and $\mathrm{Gd}\left(\mathrm{NO}_{3}\right)_{3}$ aqueous solutions toward $S$. aureus (treatment conditions: $5 \%$ o.w.f, $98^{\circ} \mathrm{C}, 40 \mathrm{~min}$ )

\begin{tabular}{|c|c|c|c|}
\hline \multirow[t]{2}{*}{ Agent } & \multicolumn{2}{|c|}{ Logarithm of viable bacteria count } & \multirow{2}{*}{$\begin{array}{l}\text { Anti- } \\
\text { bacterial } \\
\text { activity }\end{array}$} \\
\hline & $\begin{array}{l}\text { Just after inocu- } \\
\text { lation }\end{array}$ & After culturing & \\
\hline $\mathrm{Ce}\left(\mathrm{NO}_{3}\right)_{3}$ & 4.35 & 2.32 & 4.7 \\
\hline $\mathrm{La}\left(\mathrm{NO}_{3}\right)_{3}$ & 4.30 & $<1.3$ & $>5.8$ \\
\hline $\mathrm{Gd}\left(\mathrm{NO}_{3}\right)_{3}$ & 4.40 & $<1.3$ & $>5.9$ \\
\hline
\end{tabular}

When the unchlorinated wool fabric was treated with a more concentrated $\mathrm{Ce}\left(\mathrm{NO}_{3}\right)_{3}$ solution (12\% o.w.f), either at room temperature $\left(20-25^{\circ} \mathrm{C}\right)$ for $48 \mathrm{~h}$ or at $98^{\circ} \mathrm{C}$ for $2 \mathrm{~h}$, the fabric adsorbed enough $\mathrm{Ce}^{3+}$ to display excellent antibacterial activity toward $S$. aureus (approximately 5.6, Table 5). A similar trend was observed toward E. coli (antibacterial activity: approximately 6.2).

To explore the application potential for other natural fabrics, we also used the $\mathrm{Ce}\left(\mathrm{NO}_{3}\right)_{3}$ aqueous solution to treat woven silk and cotton fabrics. The corresponding results are shown in Table 6 . The as-treated silk and cotton exhibited antibacterial activities of 5.8 and 5.2, respectively, which were reduced after 50 washes to 2.9 and 4.8 , respectively. 
Table 5 Antibacterial activity of the unchlorinated woven wool fabric toward $S$. aureus and $E$. coli following treatments with $\mathrm{Ce}\left(\mathrm{NO}_{3}\right)_{3}$ aqueous solution at $12 \%$ o.w.f

\begin{tabular}{llllll}
\hline Bacteria & Sample & Treatment conditions & \multicolumn{2}{l}{ Logarithm of viable bacteria count } & $\begin{array}{l}\text { Antibacte- } \\
\text { rial activity }\end{array}$ \\
\cline { 4 - 5 } & & & $\begin{array}{l}\text { Just after } \\
\text { inoculation }\end{array}$ & After culturing & \\
\hline S. aureus & Wool & $12 \%$ o.w.f, RT, $48 \mathrm{~h}$ & 4.4 & $<1.3$ & $\geq 5.6$ \\
& & $12 \%$ o.w.f, $98^{\circ} \mathrm{C}, 2 \mathrm{~h}$ & 4.4 & $<1.3$ & $\geq 5.6$ \\
E. coli & Wool & $12 \%$ o.w.f, $\mathrm{RT}, 48 \mathrm{~h}$ & 4.4 & $<1.3$ & $\geq 6.2$ \\
& & $12 \%$ o.w.f, $100^{\circ} \mathrm{C}, 2 \mathrm{~h}$ & 4.4 & $<1.3$ & $\geq 6.2$ \\
\hline
\end{tabular}

Table 6 Antibacterial activity of woven wool, silk, and cotton treated with $\mathrm{Ce}\left(\mathrm{NO}_{3}\right)_{3}$ aqueous solution toward $\mathrm{S}$. aureus (treatment conditions: $5 \%$ o.w.f; $40 \mathrm{~min}$; wool: $98{ }^{\circ} \mathrm{C}$, silk and cotton: $65^{\circ} \mathrm{C}$ )

\begin{tabular}{lllll}
\hline Sample & $\begin{array}{l}\text { Washing } \\
\text { condition }\end{array}$ & $\begin{array}{l}\text { Logarithm of viable bacte- } \\
\text { ria count }\end{array}$ & $\begin{array}{l}\text { Antibacte- } \\
\text { rial activity }\end{array}$ \\
\cline { 3 - 4 } & & $\begin{array}{l}\text { Just after } \\
\text { inocula- } \\
\text { tion }\end{array}$ & After culturing & \\
\hline Wool $^{\mathrm{a}}$ & Before washing & 4.35 & 2.32 & 4.7 \\
& After 10 washes & 4.35 & 2.31 & 4.7 \\
& After 50 washes & 4.36 & 3.20 & 3.9 \\
Silk & Before washing & 4.30 & 1.22 & 5.8 \\
& After 10 washes & 4.21 & 3.42 & 3.6 \\
& After 50 washes & 4.39 & 4.09 & 2.9 \\
Cotton & Before washing & 4.40 & 1.91 & 5.2 \\
& After 10 washes & 4.36 & 2.05 & 4.9 \\
& After 50 washes & 4.34 & 2.22 & 4.8 \\
\hline
\end{tabular}

${ }^{\mathrm{a} C h l o r i n a t e d ~ w o o l ~}$

\section{Generation of active oxygen free radicals}

To examine the generation of free active oxygen radicals, we recorded the ESR spectra of $\mathrm{H}_{2} \mathrm{O}_{2}$ aqueous solutions following the immersion of wool and silk fabrics with and without adsorbed rare-earth ions $\left(\mathrm{Ce}^{3+}, \mathrm{La}^{3+}\right.$, or $\mathrm{Gd}^{3+}$ on wool; $\mathrm{Ce}^{3+}$ on silk). The spectra (Fig. 3a, b) showed no peaks in the 3480-3550 G range when the sample did not contain rareearth ions. In contrast, all fabrics treated with rare-earth ions demonstrated peaks corresponding to significant amounts of -OH radicals (Frejaville et al. 1995).

\section{Safety and potential of cerium nitrate in the antibacterial treatment for wool}

We examined the safety of the $\mathrm{Ce}\left(\mathrm{NO}_{3}\right)_{3}$ immersion liquid used for the antibacterial treatment through several tests. First, we employed a human 3D cultured epidermis model to evaluate whether $\mathrm{Ce}\left(\mathrm{NO}_{3}\right)_{3}$ was a skin irritant. The cell viability with $\mathrm{Ce}\left(\mathrm{NO}_{3}\right)_{3}$ was $72.5 \%$ (100\% under distilled water), which exceeded the judgment criterion of $50 \%$.
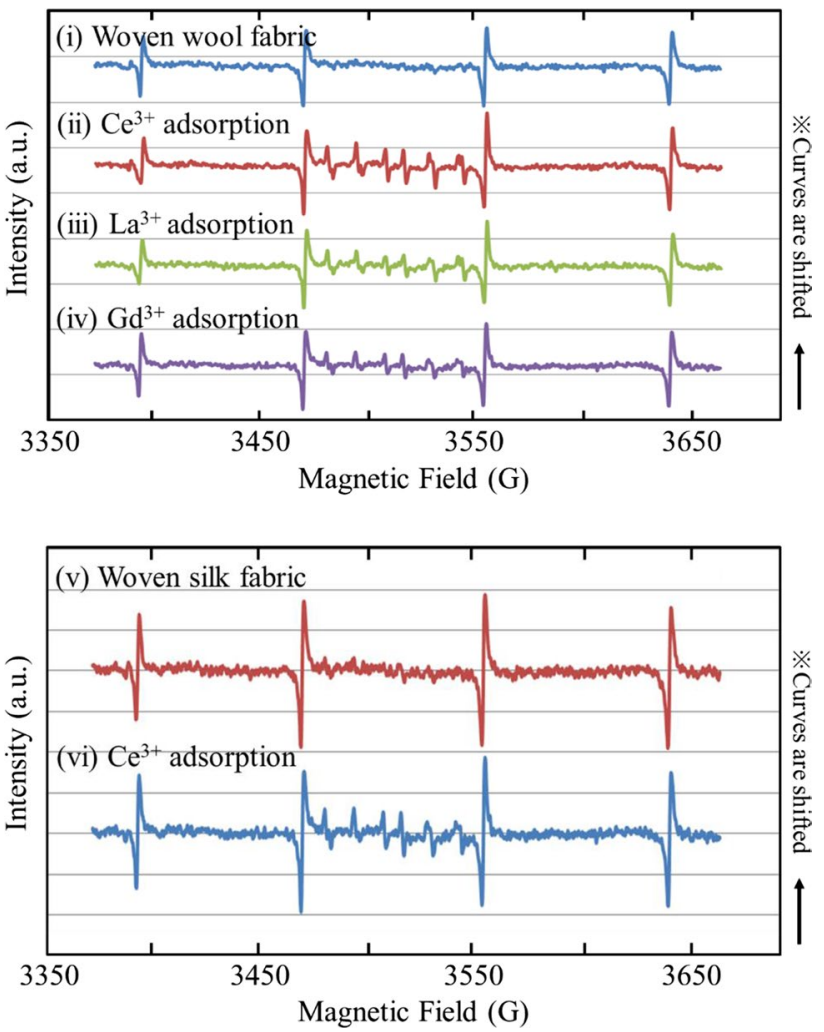

Fig. 3 a ESR spectra of woven wool fabric (i) in the as-provided state and after the adsorption of (ii) $\mathrm{Ce}^{3+}$, (iii) $\mathrm{La}^{3+}$, and (iv) $\mathrm{Gd}^{3+}$. b ESR spectra of woven silk fabric (v) in the as-provided state and (vi) after adsorption of $\mathrm{Ce}^{3+}$. In all cases, the aqueous solution contained 1.6 $\mu \mathrm{M} \mathrm{H}_{2} \mathrm{O}_{2}$, and the immersion time was $30 \mathrm{~min}$

Therefore, under the conditions of this test, it was judged to be a "non-irritant" (GHS classification). In the next test, the presence or absence of microbial mutagenesis by $\mathrm{Ce}\left(\mathrm{NO}_{3}\right)_{3}$ in S. typhimurium and E. coli was investigated, and the number of revertant mutant colonies in all test strains was less than twice the reference value; therefore, $\mathrm{Ce}\left(\mathrm{NO}_{3}\right)_{3}$ was judged to have a "non-mutagenic ability." For the third test, LLNA: BrdU-ELISA was performed on female CBA/J mice to determine whether or not $\mathrm{Ce}\left(\mathrm{NO}_{3}\right)_{3}$ was a skin sensitizer using a stimulation index (SI) as an indicator. The 
SI was $<1.6$, which indicated "non-sensitization." Finally, during the acute oral toxicity study, no severe adverse reactions, including death, were seen in all the five rats, and no abnormalities were observed in the general condition or body weight of the rats. However, because borderline protuberance projection of the forestomach was observed in one rat at autopsy, the hazard classification for acute toxicity to rats due to oral administration of $\mathrm{Ce}\left(\mathrm{NO}_{3}\right)_{3}$ under the conditions of this study was "Category 5" (GHS). These results demonstrate the safety of $\mathrm{Ce}\left(\mathrm{NO}_{3}\right)_{3}$.

\section{Discussion}

\section{Influence of chlorination on rare-earth adsorption}

The SEM images (Fig. 2) show no noticeable disintegration of the wool, indicating that the fabric quality was retained. In addition, the absence of cerium particles on the surface suggests that cerium may be attached to the fiber surface in the form of an ionic complex.

Chlorination increased the recovery for each type of rareearth ion in supplementary Fig. S-2. Such enhancement is attributed to sulfonic acid groups $\left(-\mathrm{SO}_{3} \mathrm{H}\right)$ generated by oxidation of disulfide bonds in the wool scale, and partial cleavage of the polypeptide chain to produce hydrophilic groups $\left(-\mathrm{OH},-\mathrm{COOH}\right.$, and $\left.-\mathrm{NH}_{2}\right)$. Thus, $\mathrm{Ce}^{3+}$ and other metal cations in the solution are attracted strongly to the surface groups (e.g., imidazole in histidine and carboxyl and sulfonic acid groups) and bind to the wool fibers (Kawahara 1981).

\section{Antibacterial activity}

The 5\% o.w.f $\mathrm{Ce}\left(\mathrm{NO}_{3}\right)_{3}$ aqueous solution contains nitric acid and is strongly acidic ( $\mathrm{pH}^{<1)}$ (Table 1$)$. For example, wool decomposes in hot concentrated sulfuric acid. Because $\mathrm{Ce}\left(\mathrm{CH}_{3} \mathrm{COO}\right)_{3}$ aqueous solution at the same concentration has a significantly higher $\mathrm{pH}$ (3.8), we assume that it causes less damage to the wool while still imparting antibacterial properties. Treatment at high temperature increases the number of collisions between $\mathrm{Ce}^{3+}$ ions and adsorption sites on the wool surface due to enhanced molecular movement. Because of its low quantity, we could not directly observe cerium on the fiber using SEM in association with the energy-dispersive X-ray technique. However, the high antibacterial activity before and after washing can be attributed to the strong adsorption of cerium ions. A previous study found that adsorbing Ag onto natural fibers such as wool and silk imparts antibacterial properties (Tsukada 2004); however, the fibers were stained black during this process. In contrast, the wool was not significantly discolored after the cerium-based antibacterial treatment used in the present study. Therefore, the proposed treatment does not affect the natural color of the fabric or its subsequent dyeing.

In Table 2, cerium demonstrates antibacterial activity regardless of its valence. $\mathrm{Ce}^{4+}$ is relatively stable in oxidizing acidic solutions (such as sulfuric acid and nitric acid), but it can be gradually converted to $\mathrm{Ce}^{3+}$ by redox reaction with the exchanger and possibly oxidized to $\mathrm{Ce}^{4+}$ again (Sanpei et al. 2002). The ability of cerium to cycle between $\mathrm{Ce}^{3+}$ and $\mathrm{Ce}^{4+}$ states at oxygen vacancy sites is well known (Heckert et al. 2008). This may explain their similar antibacterial effects.

Previously, Kuang et al. (2011) demonstrated the high antibacterial activity toward $E$. coli from $\mathrm{CeO}_{2}$ powder, especially $\mathrm{CeO}_{2}$ nanoparticles. Our experiment confirmed this result (Table 3). However, the chlorinated wool fabric itself had no antibacterial effect ( -0.6 toward $S$. aureus), and there was no improvement after treating it with $10 \%$ o.w.f $\mathrm{CeO}_{2}$ suspension at $98{ }^{\circ} \mathrm{C}$ for $40 \mathrm{~min}(-0.5)$. In comparison, immersing the chlorinated woven wool fabric in $5 \%$ o.w.f $\mathrm{Ce}\left(\mathrm{NO}_{3}\right)_{3}$ aqueous solution was effective (antibacterial activity of 4.7 before washing cycles, as described in Tables 1 and 2). Therefore, compared to the $\mathrm{CeO}_{2}$ particles, cerium ions in the solution adhere much better on the fabric surface without requiring additional immobilization steps, such coating them with polymers for attachment to fibers.

The antibacterial activities of $\mathrm{La}\left(\mathrm{NO}_{3}\right)_{3}$ and $\mathrm{Gd}\left(\mathrm{NO}_{3}\right)_{3}$ were better than that of $\mathrm{Ce}\left(\mathrm{NO}_{3}\right)_{3}$ (Table 4). Therefore, nitrate aqueous solutions of multiple rare-earth ions can function as antibacterial agents. Moreover, as in the case of cerium, no discoloration was observed in the woven wool fabric treated with $\mathrm{La}\left(\mathrm{NO}_{3}\right)_{3}$ and $\mathrm{Gd}\left(\mathrm{NO}_{3}\right)_{3}$ aqueous solutions. We also found that a more concentrated $\mathrm{Ce}\left(\mathrm{NO}_{3}\right)_{3}$ solution could produce excellent antibacterial properties even in wool fabrics without chlorine pretreatment (Table 5). Therefore, the proposed antibacterial treatment has considerable versatility.

Finally, we extended the antibacterial treatment to woven silk and cotton fabrics, and cerium adsorption appeared to be stronger on cotton than silk. According to the hard and soft acids and bases theory, the carboxyl group $(-\mathrm{COOH})$ in wool is a hard base, whereas in silk and cotton, the hard base is the hydroxyl group $(-\mathrm{OH}$, from the amino acid and cellulose, respectively). $\mathrm{Ce}^{3+}$ as a hard acid is therefore expected to be easily adsorbed on silk and cotton. Importantly, silk and cotton can adsorb enough $\mathrm{Ce}^{3+}$ without any pretreatment, such as chlorination, because the functional groups involved in adsorption are already exposed.

\section{Generation of active oxygen free radicals}

The ESR spectra obtained for the samples and $\mathrm{H}_{2} \mathrm{O}_{2}$ aqueous solutions (Fig. 3a, b) reveal that all fabrics treated with rareearth solutions generated characteristic peaks, indicating the 
presence of $\cdot \mathrm{OH}$ radicals. In contrast, no peaks were observed for the fabrics without adsorbed rare-earth ions. The $\cdot \mathrm{OH}$ radicals are generated from the following series of reactions (Fenton-like reaction) (Heckert et al. 2008) that are similar to the Fenton/Haber-Weiss reaction.

$$
\begin{aligned}
& \mathrm{Ce}^{3+}+\mathrm{H}_{2} \mathrm{O}_{2}+\mathrm{H}^{+} \rightarrow \mathrm{Ce}^{4+}+\cdot \mathrm{OH}+\mathrm{H}_{2} \mathrm{O} \\
& \cdot \mathrm{OH}+\mathrm{H}_{2} \mathrm{O}_{2} \rightarrow \mathrm{HO}_{2}^{-}+\mathrm{H}_{2} \mathrm{O} \\
& \mathrm{Ce}^{4+}+\mathrm{HO}_{2}^{-} \rightarrow \mathrm{O}_{2}+\mathrm{Ce}^{3+}+\mathrm{H}^{+}
\end{aligned}
$$

The metabolic activity in bacteria generates $\mathrm{H}_{2} \mathrm{O}_{2}$, which diffuses through the cell membrane and can be detected in the extracellular space (Patella et al. 2021) and can become co-adsorbed with the rare-earth ions on the fabric to produce hydroxyl radicals $(\cdot \mathrm{OH})$ in accordance with Eq. (3). The strongly oxidizing $\cdot \mathrm{OH}$ (Liszkay et al. 2003) breaks down the cell walls to react with $\mathrm{H}_{2} \mathrm{O}_{2}$. This may explain the antibacterial properties of our treated fabrics. The generation of the $\mathrm{Ce}^{3+}$ ion from $\mathrm{Ce}^{4+}$ and $\mathrm{HO}^{2-}$ (obtained from Eq. (4)) can be attributed to the instability associated with the $\mathrm{Ce}^{4+}$ state in Eq. (5). Therefore, the antibacterial activity of cerium ions is expected to be retained for a long period. Besides the generation of $\cdot \mathrm{OH}$ from $\mathrm{H}_{2} \mathrm{O}_{2}$ (confirmed by ESR in this study), other factors may also contribute to the antibacterial properties of cerium, such as ion valence fluctuation and inactivation of enzymes (Matsumoto et al. 2020).

Owing to the mismatch between the natural abundance of different rare-earth elements and their changing market demands, there is currently an excess of light rare-earth elements, of which, cerium is dominant. The solution of this "balance problem" requires finding new ways to utilize the light rare-earth elements. This study confirmed that light rare-earth ions, especially cerium, display antibacterial effects when adsorbed on wool, cotton, and silk. Thus, these ions may be used as a safe material for treating various fabrics, with potential applications in medical facilities and disaster relief operations.

Matsumoto et al. (2020) reported that $\mathrm{CeO}_{2}$ in suspension exhibits little activity toward $\Phi 6$. In contrast, heteropoly acids containing cerium strongly inhibit the influenza virus (Liu et al. 2004). Moreover, when polyacids are adsorbed by electrostatic interaction at cationic lysine residues in the active site of human immunodeficiency virus, viral inactivation can occur due to transport of inorganic metal to the virus (Judd et al. 2001). In the present study, the adsorption of rare-earth ions (e.g., cerium) on wool can be attributed to interaction with the nitrogen in amino acids (such as histidine) to form a complex. However, such interaction does not occur with $\mathrm{CeO}_{2}$ particles. Therefore, samples containing cerium adsorbed on wool may have potential antiviral activity against SARS-CoV-2 (Ito et al. 2021). Although experiments with actual virus have not been performed, it is known that lysine exists at the active site of SARS-CoV-2 (Yoshimoto 2020), and that chemical modification of lysine residue can affect protein function (such as inactivating alkaline phosphatase (Chen et al. 2005)). Cerium in complex oxides has also exhibited a high alkaline phosphatase enzyme inactivation rate (Matsumoto et al. 2020), which implies that inactivation of enzyme proteins such as alkaline phosphatase is a potential mechanism of antibacterial activity, in addition to the pseudo-Fenton reaction caused by reactive oxygen species, as supported by the results in present study. Cerium ions adsorbed on basic amino acids (arginine, lysine, and histidine) (Craig et al. 1954) in wool can potentially move to the lysine side chains of viruses attached to the wool surface and cause viral inactivation. Manufacturing fabrics with antimicrobial properties would make it easier to disinfect clothes and other items. In particular, if fabrics containing cerium ions are effective against enveloped viruses, then they may be used in face masks, medical uniforms and scrubs, patient gowns, bedclothes, and so on, to help combat COVID-19 and other infectious diseases in the future. The related research should be carried out in collaboration with medical researchers and clinicians.

\section{Conclusions}

We introduced cerium, a light rare-earth element with declining demand in recent years, into woven wool fabric as a potential antibacterial agent. The wool fabric was first chlorinated to remove the cuticle layer on the fiber surface, enhancing the adsorption of different rare-earth ions. The antibacterial treatment involves immersing the fabric in a $\mathrm{Ce}\left(\mathrm{NO}_{3}\right)_{3}$ aqueous solution at a fixed temperature for a predetermined time. The result is significant (antibacterial activity against $S$. aureus: 4.7 after treatment and 3.9 after 50 wash cycles) for chlorinated wool fabric treated with $5 \%$ o.w.f cerium at $98{ }^{\circ} \mathrm{C}$ for $40 \mathrm{~min}$. The treated fabrics also showed effective values against E. coli. Similar results were observed for silk and cotton fabrics $\left(5 \%\right.$ o.w.f, $\left.65^{\circ} \mathrm{C}, 40 \mathrm{~min}\right)$ with values of 5.8 and 5.2 after treatment and 2.9 and 4.8 after 50 wash cycles, respectively. $\mathrm{La}^{3+}$ and $\mathrm{Gd}^{3+}$ also demonstrated excellent antibacterial properties when adsorbed on wool fabric (activities: approximately 5.8 and 5.9, respectively). For a milder reaction condition, $\mathrm{Ce}\left(\mathrm{CH}_{3} \mathrm{COOH}\right)_{3}$ aqueous solution could be used in place of the highly acidic $\mathrm{Ce}\left(\mathrm{NO}_{3}\right)_{3}$ solution, with comparable antibacterial activity after 40 min immersion $\left(4.9\right.$ at $65{ }^{\circ} \mathrm{C}$ and 5 at $\left.85{ }^{\circ} \mathrm{C}\right)$. The observed antibacterial effects can be attributed to $\cdot \mathrm{OH}$ radicals formed during the Fenton reaction involving the 
$\mathrm{H}_{2} \mathrm{O}_{2}$ produced in microbial metabolism under the catalytic action of $\mathrm{Ce}^{3+}, \mathrm{La}^{3+}$, or $\mathrm{Gd}^{3+}$. This was supported by the observation of $\cdot \mathrm{OH}$ radical peaks in the ESR spectral profiles, when $\mathrm{H}_{2} \mathrm{O}_{2}$ aqueous solution was added with fabrics containing rare-earth ions $\left(\mathrm{Ce}^{3+}, \mathrm{La}^{3+}\right.$, and $\mathrm{Gd}^{3+}$ for wool; and $\mathrm{Ce}^{3+}$ for silk). In the future, this method of imparting antibacterial properties could be applied to personal clothing as well as medical and first-aid supplies (such as masks, patient gowns, and bandages).

Supplementary Information The online version contains supplementary material available at https://doi.org/10.1007/s11696-021-01999-9.

Acknowledgements We thank The Japan Wool Textile Co., Ltd., and Santoku Corporation for providing the fabric and rare-earth liquid samples, respectively.

Funding This research did not receive any specific grant from funding agencies in the public, commercial, or not-for-profit sectors.

Data availability All data generated or analyzed during this study are included in this published article.

\section{Declarations}

Conflict of interest The authors declare that they have no conflict of interest.

Human or animal rights The above-mentioned tests were conducted at the Japan Chemical Innovation and Inspection Institute in accordance with the following laws, guidelines, and standards: (a) Act on the Welfare and Management of Animals, Law No. 105, 1973; (b) Standards for the Care and Custody of Animal Experiments and for the Alleviation of Pain and Suffering, Japan's Ministry of the Environment, 2006; (c) Basic Guidelines for the Implementation of Animal Experiments, etc., in Institutions Complementary to the Ministry, Japan's Ministry of Health, Labour and Welfare, 2006; (d) Basic Guidelines for the Implementation of Animal Experiments, etc., in Research Institutions under the Jurisdiction of the Ministry, Japan's Ministry of Agriculture, Forestry and Fisheries, 2006; (e) Basic Guidelines for the Implementation of Animal Experiments, etc., in Research Institutions, etc., Japan's Ministry of Education, Culture, Sports, Science and Technology, 2006; and (f) Guidelines for the Appropriate Implementation of Animal Experiments, Science Council of Japan, 2006.

\section{References}

Akioka S, Hirai S, Ise T, Gando N, Alharbi MAH (2021) Selective recovery of palladium by wool resin and woven wool fabric resinrbents. Hydrometallurgy 203:105629. https://doi.org/10.1016/j. hydromet.2021.105629

Bekrani M, Zohoori S, Davodiroknabadi A (2020) Producing multifunctional cotton fabrics using nano $\mathrm{CeO} 2$ doped with nano $\mathrm{TiO} 2$ and ZnO. Autex Res J 20:78-84. https://doi.org/10.2478/ aut-2019-0057

Bradbury JH (1973) The structure and chemistry of keratin fibers. Adv Protein Chem 27:111-211. https://doi.org/10.1016/S00653233(08)60447-7
Chen HT, Xie LP, Yu ZY, Xu GR, Zhang RQ (2005) Chemical modification studies on alkaline phosphatase from pearl oyster (Pinctada fucata): a substrate reaction course analysis and involvement of essential arginine and lysine residues at the active site. Int J Biochem Cell Biol 37:1446-1457. https://doi.org/10.1016/j.biocel. 2005.02.002

Craig JP Jr, Garrett AG, Williams HB (1954) The ovalbumin-chloroauric acid reaction. J Am Chem Soc 76:1570-1575. https://doi. org/10.1021/ja01635a028

Cuadrado JA, Zhang W, Hang W, Majidi V (2000) Speciation of gold(III)-L-histidine complex: a multi-instrumental approach. J Environ Monit 2:355-359. https://doi.org/10.1039/b000085j

Dural-Erem A, Erem HH, Ozcan G, Skrifvars M (2015) Anatase titanium dioxide loaded polylactide membranous films: preparation, characterization, and antibacterial activity assessment. J Text Inst 106:571-576. https://doi.org/10.1080/00405000.2014.929274

Espitia PJP, Soares ND, dos Reis Coimbra JS, de Andrade NJ, Cruz RS, Medeiros EA (2012) Zinc oxide nanoparticles: synthesis, antimicrobial activity and food packaging applications. Food Bioprocess Technol 5:1447-1464. https://doi.org/10.1007/ s11947-012-0797-6

Frejaville C, Karoui H, Tuccio B, Moigne FL, Culcasi M, Pietri S, Lauricella R, Tordo P (1995) 5-(Diethoxyphosphoryl)-5-methyl-1-pyrroline $\mathrm{N}$-oxide: a new efficient phosphorylated nitrone for the in vitro and in vivo spin trapping of oxygen-centered radicals. J Med Chem 38:258-265. https://doi.org/10.1021/ jm00002a007

Galal I, El-Hindawy K (2011) Impact of using triclosan-antibacterial sutures on incidence of surgical site infection. Am J Surg 202:133-138. https://doi.org/10.1016/j.amjsurg.2010.06.011

Gaya UI, Abdullah AH (2008) Heterogeneous photocatalytic degradation of organic contaminants over titanium dioxide: a review of fundamentals, progress and problems. J Photochem Photobiol 9:1-12. https://doi.org/10.1016/j.jphotochemrev.2007.12.003

Ghiasi Y, Davodiroknabadi A, Zohoori S (2021) Electrospinning of wheat bran cellulose $/ \mathrm{TiO}_{2} / \mathrm{ZnO}$ nanofibre and investigating the UV blocking and bactericidal properties. Bull Mater Sci 44:89. https://doi.org/10.1007/s12034-021-02406-5

Hadrup N, Sharma K.A, Loeschner K (2018) Toxicity of silver ions, metallic silver, and silver nanoparticle materials after in vivo dermal and mucosal surface exposure: A review. Regul Toxicol Pharmacol 98:257-267. https://doi.org/10.1016/j.yrtph.2018.08.007

Heckert EG, Seal S, Self WT (2008) Fenton-like reaction catalyzed by the rare earth inner transition metal cerium. Environ Sci Technol 42:5014-5019. https://doi.org/10.1021/es8001508

Imlay J, Chin S, Linn S (1988) Toxic DNA damage by hydrogen peroxide through the Fenton reaction in vivo and in vitro. Science 240:640-642. https://doi.org/10.1126/science.2834821

International Wool Textile Organisation (2016) IWTO Market Information Edition 16. https://iwto.org/wp-content/uploads/2021/03/20210 315_IWTO_MI_DigitalSample.pdf Accessed 20 October 2021

Ito T, Sunada K, Nagai T, Ishiguro H, Nakano R, Suzuki Y, Nakano A, Yano H, Isobe T, Matsushita S, Nakajima A (2021) Preparation of cerium molybdates and their antiviral activity against bacteriophage $\Phi 6$ and SARS-CoV-2. Mater Lett 290:129510. https://doi. org/10.1016/j.matlet.2021.129510

Izatt RM, Christensen JJ, Rytting JH (1971) Sites and thermodynamic quantities associated with proton and metal ion interaction with ribonucleic acid, deoxyribonucleic acid, and their constituent bases, nucleosides, and nucleotides. Chem Rev 71:439. https:// doi.org/10.1021/cr60273a002

Japan Oil, Gas and Metals National Corporation (JOGMEC) (2015) The latest trends in rare earths (in Japanese). http://mric.jogmec. go.jp/public/kouenkai/2015-08/20150828_04.pdf. Accessed 07 April 2021 
Judd DA, Nettles JH, Nevins N, Snyder JP, Liotta DC, Tang J, Ermolieff J, Schinazi RF, Hill CL (2001) polyoxometalate HIV-1 protease inhibitors. A new mode of protease inhibition. J Am Chem Soc 123:886-897. https://doi.org/10.1021/ja001809e

Kawahara K (1981) Problems for manufacturing machine washable wool garments and their care instructions. J Text Mach Soc Jpn 34:P175-P182. https://doi.org/10.4188/transjtmsj.34.3_p175

Kuang Y, He X, Zhang Z, Li Y, Zhang H, Ma Y, Wu Z, Chai Z (2011) Comparison study on the antibacterial activity of nano- or bulkcerium oxide. J Nanosci Nanotechnol 11:4103-4108. https://doi. org/10.1166/jnn.2011.3858

Kulkarni VG, Baumann H (1980) Studies on some wool components: skin flakes, cuticle, and cell membrane material. Text Res J 50:69. https://doi.org/10.1177/004051758005000102

Lin Y, Yang Z, Cheng J (2007) Preparation, characterization and antibacterial property of cerium substituted hydroxyapatite nanoparticles. J Rare Earths 25:452-456. https://doi.org/10.1016/S10020721(07)60455-4

Liszkay A, Kenk B, Schopfer P (2003) Evidence for the involvement of cell wall peroxidase in the generation of hydroxyl radicals mediating extension growth. Planta 217:658-667. https://doi.org/10. 1007/s00425-003-1028-1

Liu Z (2007) Research on rare earth cerium in antibacterial finishing of wool and cotton. Master's thesis, Qingdao University, China

Liu J, Mei WJ, Xu AW, Tan CP, Shi S, Ji LN (2004) Synthesis, characterization and antiviral activity against influenza virus of a series of novel manganese-substituted rare earth borotungstates heteropolyoxometalates. Antiviral Res 62:65-71. https://doi.org/10. 1016/j.antiviral.2003.12.004

Lu G, Wu D, Fu R (2007) Studies on the synthesis and antibacterial activities of polymeric quaternary ammonium salts from dimethylaminoethyl methacrylate. React Funct Polym 67:355-366. https://doi.org/10.1016/j.reactfunctpolym.2007.01.008

Manikandan A, Manikandan E, Meenatchi B, Vadivel S, Jaganathan SK, Ladchumananandasivam R, Henini M, Maaza M, Aanand JS (2017) Rare earth element (REE) lanthanum doped zinc oxide (La: $\mathrm{ZnO}$ ) nanomaterials: synthesis structural optical and antibacterial studies. J Alloy Compd 723:1155-1161. https://doi.org/ 10.1016/j.jallcom.2017.06.336

Matsumoto T, Sunada K, Nagai T, Isobe T, Matsushita S, Ishiguro $\mathrm{H}$, Nakajima A (2019) Preparation of hydrophobic $\mathrm{La}_{2} \mathrm{Mo}_{2} \mathrm{O}_{9}$ ceramics with antibacterial and antiviral properties. J Hazard Mater 378:120610. https://doi.org/10.1016/j.jhazmat.2019.05.003

Matsumoto T, Sunada K, Nagai T, Isobe T, Matsushita S, Ishiguro H, Nakajima A (2020) Effects of cerium and tungsten substitution on antiviral and antibacterial properties of lanthanum molybdate. Mater Sci Eng C Mater Biol Appl 117:111323. https://doi.org/10. 1016/j.msec.2020.111323

Morimoto S, Seo Y (2014) Current trend of medium-long term rare earth demand forecast. J Min Mater Process Inst Jpn 130:219-224. https://doi.org/10.2473/journalofmmij.130.219

Nose K, Okabe TH (2012) Current status and problems of rare metals. J Surf Finish Soc Jpn 63:618-624. https://doi.org/10.4139/ sfj.63.618

Patella B, Buscetta M, Di Vincenzo S, Ferraro M, Aiello G, Sunseri C, Pace E, Inguanta R, Cipollina C (2021) Electrochemical sensor based on $\mathrm{rGO} / \mathrm{Au}$ nanoparticles for monitoring $\mathrm{H}_{2} \mathrm{O}_{2}$ released by human macrophages. Sens Actuators B 327:128901. https://doi. org/10.1016/j.snb.2020.128901
Pourkhorsandi H, Debaille V, de Jong J, Armytage RMG (2021) Cerium stable isotope analysis of synthetic and terrestrial rock reference materials by MC-ICPMS. Talanta 224:121877. https:// doi.org/10.1016/j.talanta.2020.121877

Ren M, Ning P, Xu J, Qu G, Xie R (2018) Concentration and treatment of ceric ammonium nitrate wastewater by integrated electrodialysis-vacuum membrane distillation process. Chem Eng J 351:721-731. https://doi.org/10.1016/j.cej.2018.06.155

Russell AD, Hugo WB (1994) Antimicrobial activity and action of silver. Prog Med Chem 31:351-370. https://doi.org/10.1016/ S0079-6468(08)70024-9

Sanpei T, Arai T, Wei Y, Kumagai M, Takeda K (2002) Studies on the anion exchange separation of tetravalent cerium in nitric acid solution. J Ion Exch 13:2-9. https://doi.org/10.5182/jaie.13.2

Shah V, Shah S, Shah H, Rispoli FJ, McDonnell KT, Workeneh S, Karakoti A, Kumar A, Seal S (2012) Antibacterial activity of polymer coated cerium oxide nanoparticles. PLoS ONE 7:e47827. https://doi.org/10.1371/journal.pone.0047827

Tsukada M (2004) Development of production and utilization technologies for functional silk protein (in Japanese). Kagaku Seibutsu 42:454-458. https://doi.org/10.1271/kagakutoseibutsu1962.42. 454

Valko M, Morris H, Cronin M (2005) Metals, toxicity and oxidative stress. Curr Med Chem 12:1161-1208. https://doi.org/10.2174/ 0929867053764635

Wang H, Zhang Y, Huang B, Deng W, Quan Y, Wang W, Xu W, Zhao Y, Li N, Zhang J, Liang H, Bao L, Xu Y, Ding L, Zhou W, Gao H, Liu J, Niu P, Zhao L, Zhen W, Fu H, Yu S, Zhang Z, Xu G, Li C, Lou Z, Xu M, Qin C, Wu G, Gao GF, Tan W, Yang X (2020) Development of an inactivated vaccine candidate, BBIBP-CorV, with potent protection against SARS-CoV-2. Cell 182:713-721. e9. https://doi.org/10.1016/j.cell.2020.06.008

Wen H, Dan M, Yang Y, Lyu J, Shao A,Cheng X, Chen L, Xu L (2017) Acute toxicity and genotoxicity of silver nanoparticle in rats. PLoS ONE 12:e0185554. https://doi.org/10.1371/journal. pone. 0185554

Yamamoto N (1999) Classification and antibacterial mechanism of inorganic antibacterial agents. Inorg Mater 6:468-473. https:// doi.org/10.11451/mukimate1994.6.468

Yamamoto O, Sawai J (2002) Antibacterial characteristics of carbon materials containing ceramic fine particles and their evaluation techniques. TANSO 204:174-181. https://doi.org/10.7209/tanso. 2002.174

Yoshimoto FK (2020) The proteins of severe acute respiratory syndrome Coronavirus-2 (SARS CoV-2 or n-COV19), the cause of COVID-19. Protein J 39:198-216. https://doi.org/10.1007/ s10930-020-09901-4

Yuan X, Tay Y, Dou X, Luo Z, Leong DT, Xie J (2013) Glutathioneprotected silver nanoclusters as cysteine-selective fluorometric and colorimetric probe. Anal Chem 85:1913-1919. https://doi. org/10.1021/ac3033678

Zhang Y, Zhong SL, Zhang M, Lin Y (2009) Antibacterial activity of silver-loaded zeolite A prepared by a fast microwave-loading method. J Mater Sci 44:457-462. https://doi.org/10.1007/ s10853-008-3129-5

Publisher's Note Springer Nature remains neutral with regard to jurisdictional claims in published maps and institutional affiliations. 